\title{
Colonial Values and Asylum Care in Brazil: Reclaiming the Streets Through Carnival in Rio de Janeiro
}

\author{
Julia Evangelista and William A. Fulford
}

\subsection{Introduction}

Brazil's cultural values are intrinsically linked to its colonial past. The country was transformed almost overnight from a colonial Portuguese outpost to the country's official seat of government when its royal family and entourage of 15,000 courtiers fled Napoleon Bonaparte's forces to arrive en masse on 22 January 1808. Rio de Janeiro was anointed its new capital city which was quickly "Europeanised" through a huge programme of infrastructural investment. European cultural values were established as infinitely superior and in direct contrast to any of the myriad of nonEuropean cultural values that had existed pre-1808. The poor, who were predominantly of native Indian and African descent, were seen as a barrier to this Europeanising project as their behaviour and customs were labelled "mad" and uncivilised [1]. No longer welcomed in the city's modernising centres, they were criminalised and displaced to the outskirts of the city, often finding themselves arbitrarily incarcerated in the newly built networks of prisons and asylums that came to dominate Rio de Janeiro's suburbs. It is in one of these suburban-built asylums, a sprawling 20-acre complex first opened in 1911 - the Pedro II Psychiatric Centre, later renamed the Nise da Silveira Institute-where the carnival project, Loucura Suburbana, continues to challenge both the divisive legacy of Brazil's colonial past and stigmas associated with mental illness.

Carnival emerged as a form of resistance against the forces of colonialism in the second half of the nineteenth century, challenging the right for the disenfranchised to occupy the city on their own cultural terms, even if only temporarily and often at

\footnotetext{
J. Evangelista

Centre for Cultural and Media Policy Studies, The University of Warwick, Coventry, UK

W. A. Fulford $(\bowtie)$

Faculty of Architecture and the Built Environment, The University of Westminster,

London, UK 
great personal risk. The main language of this occupation was a form of music and dance called "samba" that emerged from Brazil's segregated quilombos, ${ }^{1}$ favelas and suburbs, and it is within this context that samba has been described as "resistance in motion" [2]. But today, resistance plays little role in the commercial activities and VIP areas of the main carnival parades. This remains the domain of local "bloc" or neighbourhood carnivals like Loucura Suburbana, who are using "resistance in motion" in their neighbourhood of Engenho de Dentro to provide platforms for diverse and repressed forms of cultural expression.

The project is illustrated here by the story of patient Elisama Ranoud (her real name, used at her request) and psychologist Ariadne Mendes (again her real name and used at her request). ${ }^{2}$ Their story shows that it is the project's capacity to enable groups of diverse individuals to express a whole range of differing cultural values in both intimate semi-public and extrovert very-public expressions of solidarity that helps challenge fixed notions of identity and space that become barriers to recovery.

\subsection{The Story of "Patient" Elisama and Psychologist, Ariadne}

Elisama first came to the Nise da Silveira Institute in 1991 as a young mother seeking help for her 5-year-old son who had been diagnosed with a hyperactive disorder. A community centre had been set up in one of the Institute's abandoned buildings, and on the recommendation of her son's psychologist, she signed him up for some of the free activities they were offering.

Elisama and her son attended these activities alongside a family support group until he turned 18 years old in 2003. But although her son's mental well-being improved significantly over this period, Elisama's own mental health had started to deteriorate. This deterioration was driven in part by her son no longer being so dependent on her, which was obviously a good thing, albeit one that left Elisama with a gap in her own life. This sense of loss was compounded by an unfulfilling and poorly paid job as a cleaner and a broken marriage with a controlling husband and father-in-law she could not escape due to a lack of financial resources. Now 39 years old, her behaviour spiralled out of control and she fell into a deep depression: "I began to cry all the time and I thought about bad things and didn't even want to leave the house. I had no perspective and I increasingly withdrew myself from the world."

Her increasingly dishevelled appearance made her feel like an outcast from society. She was called "mad" by her neighbours and was losing her sense of identity and self-worth. Elisama's son's psychologist had also noticed these changes and recommended she seek out help at an adult support group at the Nise da Silveira Institute that was being supervised by Ariadne. In 2005, Ariadne took direct control

\footnotetext{
${ }^{1}$ Quilombos were settlements located in places hard to access created by fugitive slaves who resisted slavery.

${ }^{2}$ Using their real names when reporting on the Loucura Suburbana project is seen as an important part of the process of reclaiming citizenship and validity as producers of culture.
} 
of this group, and when it was disbanded about a year later she took Elisama on as a patient, in part because she was concerned about her being medicalised by other doctors who did not understand her case history: "I could understand that Elisama's case wasn't about taking drugs as she had already started improving and doing other recommended activities [being held at the Institute] such as Tai Chi and drawing classes."

Meanwhile, in 2000, Ariadne was part of a small group that founded the carnival project Loucura Suburbana, inspired in part by other projects that were bringing people from the local community into the psychiatric centre to attend workshops and classes alongside patients. Loucura Suburbana was designed to take this one step further by not only bringing people from the local community into the psychiatric centre to prepare for the carnival, but also then collectively taking to the streets patients and non-patients together - to parade through their local neighbourhood.

In 2006, Elisama joined the project. At first, she stayed in the background, using her experience growing up with her aunt and uncle in the culture of the Barracão, the name for the place where the carnival costumes and props are made, which also often serves as a rehearsal and social space for those taking part in the carnival. Elisama worked for 3 years helping organise Loucura Suburbana's Barracão: "which was nothing like it is today," she says proudly, "it was a mess and there weren't many costumes like there are now." It was in the Barracão where Elisama began to define a new role for herself that not only enabled her own recovery but also helped others in the process.

I make hats, I dress everybody, I normally get late because I want to get everybody dressed with makeup...Someone tells me "I want to be a Baiana" then I go and make them a costume of a Baiana, or I want to be this or that... What matters in these stories is that we do not forget that they touch our soul. There was a man who was hospitalized in an emergency here, but he heard about me and was curious to meet me and asked to see me. So, the doctor who was looking after him came down and told me, "my patient wants to see you because he dreams of wearing a wig." He was bald, so I found a wig and gave it to him. He could not go to the carnival parade, but he left happy dancing with his wig.

In 2009, the carnival bloc was looking for a new Porta Bandeira, an important symbolic figure in carnival folklore who leads the parade dressed in bright flamboyant clothes and makeup. Buoyed by her increased confidence working in the Barracão, Elisama volunteered. This new very public role represented a step change in her recovery, giving Elisama the chance to present a version of herself to her local neighbourhood that moved beyond the stereotyped image of someone suffering from mental illness in which she felt she had been trapped.

When I went to the streets for the first time, the local people showed prejudice, because I live here. But the way and the moment that door was opened to me and I exited the hospital, many things changed, because now the people themselves take part in the bloc, they accept me and give me compliments and say very good things about the centre. Because when you talk about a psychiatric hospital, people think horrible things, that we will be aggressive

\footnotetext{
${ }^{3} \mathrm{~A}$ Baiana is a distinctive traditional form of dress typical of women from Bahia in the north east of the country that has strong Afro-Brazilian roots.
} 
towards them, and this is not true. We are people like anybody else. We just need to be looked after... If you give us opportunity, it can take a little while, but we can learn. I learnt to sew, I learnt about informatics...I will never forget the day I went to the Sapucai ${ }^{4}$ with the costumes I always dreamt of...my neighbours saw me and began to see me in a different way because before I was not a Porta Bandeira... you grow as a person. You become a person you did not think you were capable of becoming.

Elisama has continued to play a prominent role both behind the scenes in the Barracão and front of house as the Porta Bandeira. In doing so, she has learnt new skills and met different people that have helped shift her own perceptions about herself and those around her. She has found her identity, or in some cases identities, and an ability, confidence and platform to express these identities both privately and publicly through the various activities of carnival.

This year I am writing...the theme is about prejudice, of race, colour, especially in relation to the condition of the woman, harassment. So, the theme is drag [as in drag queen], about the fight against stigmas. We are what we want to be. I do not want to be a "watermelon" I want to be a drag! Since 2016 I have had this in my mind... a drag is related to my thinking as a woman.

The impact of this renewed confidence has been significant. Although her personal situation - a stressful home and working life-remains largely unchanged, the support mechanisms provided by Loucura Suburbana's activities have given her better tools to cope. "I feel like I broke barriers. Everybody is capable! I have high self-esteem again! Our self-esteem grows every time the bloc grows, because at the beginning we were nothing." Such has been the impact on her health and well-being that Elisama now feels a tremendous sense of loyalty to the Nise da Silveira Institute where the project takes place and the people within it, calling for more projects like Loucura Suburbana that offer creative activities and platforms for cultural expression as alternatives to medication [3].

This sense of project loyalty is one reason why Loucura Suburbana's participants resist the idea of anonymity when talking about the project. As Ariadne explains:

I defend that [not changing names when reporting on the project] because if we want citizenship, I am not talking about clinical cases or giving diagnostics...but we are talking about human lives. Of course, I ask permission where it's required, but in general I use the real names and surnames because these people are citizens, and these are their stories.

When asked if she has ever had anyone refuse permission to use their name, she responds: "no this has never happened! In fact, it's the opposite. In the carnival bloc the name of each patient appears alongside their role in the carnival. Because everybody has a role. The Porta Bandeira or the Mestre-Sala. They all have a role to play."

\footnotetext{
${ }^{4}$ The Sapucai is the principle thoroughfare for the main carnival of Rio de Janeiro that holds 90,000 spectators and is televised internationally.

5 "Watermelon" is a derogatory caricature of a woman with a curvaceous body-type who is considered by society to have nothing to offer except for how she looks.
} 


\subsection{Colonisation, Mental Health and Carnival as Resistance}

A defining aspect of colonisation in Brazil has been the imposition of one relatively homogenous set of European cultural values over the myriad of diverse cultural values that either pre-existed or emerged during colonisation. This process of cultural imposition involved a mixture of techniques to ridicule, dehumanise and demonise those that did not fit within the narrow confines of European values and norms of behaviour, which in turn became the foundations for the construction of madness and notions of "normality" versus "deviance" that remain strong in Brazil today. As the country sought to Europeanise, hundreds of thousands of Brazilians were arbitrarily locked up in the network of asylums that were, by no coincidence, built alongside the abolishment of slavery in 1888 . This is a largely ignored period of Brazilian history, and details are only recently starting to emerge about the horrific conditions and number of unexplained deaths that occurred in many of these asylums. One author has labelled this period the Brazilian Holocaust with more than 60,000 people known to have died in one hospital alone [4].

In time, the Europeanising project extended to carnival, where the "collective" presence of white and black people in a shared space was considered a threat to the morality and social order of the country [1]. As such, people from non-European backgrounds and their associated forms of cultural expression, particularly those rooted in Afro-Brazilian religions and cultures, were banned from taking part. Carnival as resistance in the colonial context in Brazil thus emerges around the second half of the nineteenth century as a direct reaction against this cultural crackdown. By the beginning of the twentieth century, in a series of very public displays of resistance, and despite heavy and often violent responses from the police, the culturally marginalised began to venture collectively into the streets of Rio de Janeiro to express their right to the city and cultural expression through dancing and singing to the sound of drums in deliberate opposition to the polished carnival of the elite, which in general took place in the private spaces of Rio de Janeiro's clubs [5].

However, the colonial legacy in Brazil remains strong. Today, many of its asylums continue to house a disproportionate number of people from non-European backgrounds, and particularly those of African descent, fed by a toxic combination of political powerlessness, economic uncertainty and the constant bombardment of overt and more subliminal messages about cultural inferiority. This toxic combination creates a form of "disrupted self-hood" [6] that exacerbates the likelihood of such populations suffering from mental illness.

Elisama's story shows how suffering from the stigmas of mental illness created the conditions for cultural and social exclusion which only exacerbated her already perilous condition. The Loucura Suburbana carnival project enabled Elisama to resist these forces of exclusion, reasserting her right to occupy the neighbourhood from which she had felt excluded. It also gave her a platform to express her own cultural values while projecting a positive image of herself in both public and more private situations which enabled her to break free from an aspect of her history as someone who suffers from mental illness in which she had felt trapped. 


\subsection{Conclusions}

This chapter began by showing how Brazil's colonial past established European cultural values as infinitely superior to those from other cultural backgrounds. Carnival emerged as a form of resistance against such colonial processes, symbolising a time of year when marginalised communities could gather en masse to resist, even if only temporarily, such forms of cultural repression by occupying parts of the city from which they would normally be excluded and playing music and dancing to rhythms that had been rejected as uncivilised.

The story of Elisama and the Loucura Suburbana carnival project show these same forces of resistance at work. A central part of her recovery has been the opportunity to take centre stage during the carnival parades, reclaiming her right to be in a city from which she had felt excluded because of her history of mental illness. In reclaiming the streets as part of a respected carnival parade, Elisama was able to re-build her sense of identity and self-worth beyond the stereotyped image of a mental health patient within which she felt she had become trapped.

The combination of the very public and more private roles behind the scenes in the carnival project have given Elisama the tools to become a producer of culture on her own terms. She is writing her own performances and expressing her own identity, or sometimes identities, all wrapped up in her own sense of important cultural values. This combination has led to huge improvements in Elisama's general sense of mental well-being, even though her own personal circumstances that were major contributing factors in her spiral towards mental illness have remained unchanged.

Acknowledgements The authors would like to thank Psychologist Ariadne Mendes and Porta Bandeira Elisama Ranoud for their time and honesty in answering our questions during these interviews.

\subsection{Guide to Further Sources}

The authors have a wide variety of photographic and other materials illustrating the Loucura Suburbana-see for example:

- https://www.loucurasuburbana.org

- https://www.bbc.com/news/av/world-latin-america-47419917/the-carnival-paradeshining-a-light-on-mental-health

- https://vimeo.com/40817909

- https://www.youtube.com/watch?v=G-Nizn1wDJ4

- https://www.youtube.com/watch?v=uQh1ixxSkFQ

- https://www.youtube.com/watch?v=bVZ8n2ksbvo

- https://www.youtube.com/watch?v=LtBRBWpttOs 


\section{References}

1. Cunha MCP. Ecos da Folia: Uma historia social do Carnaval carioca entre 1880 e 1920. São Paulo: Companhia das Letras. p. 2001.

2. Browning B. Samba: resistance in motion. Indianapolis: Indiana University Press; 1993.

3. Evangelista J, Fulford W. Performing urbanity through carnival on the streets of Rio de Janeiro: practical approaches for reducing stigmatization of the "mad" in cities. In: Okpaku S, editor. Innovations in gloabl mental health. Cham: Springer Nature; 2019. p. 1-21.

4. Arbex D. Holocausto Brasileiro: Vida, Genocidio e 60 mil mortes no maior hospicio do Brasil. Lisboa: Guerra e Paz Editores; 2004.

5. Coutinho EG. Os Cronistas De Momo: Imprensa e Carnival na Primeira Republica. Rio de Janeiro: Editora UFRJ; 2006.

6. Selligman R. Possessing spirits and healing selves: embodiment and transformations in an Afro-Brazilian religion. New York: Palgrave Macmillan; 2015.

Open Access This chapter is licensed under the terms of the Creative Commons Attribution 4.0 International License (http://creativecommons.org/licenses/by/4.0/), which permits use, sharing, adaptation, distribution and reproduction in any medium or format, as long as you give appropriate credit to the original author(s) and the source, provide a link to the Creative Commons license and indicate if changes were made.

The images or other third party material in this chapter are included in the chapter's Creative Commons license, unless indicated otherwise in a credit line to the material. If material is not included in the chapter's Creative Commons license and your intended use is not permitted by statutory regulation or exceeds the permitted use, you will need to obtain permission directly from the copyright holder. 